an hour's haul consisted of a single crab, Paralomis sp.

In the Gulf of Oman, the upper limit of the dead area appears to lie at a slightly different level on the two sides. On the southern side in the vicinity of Muscat the great bulk of the fauna disappears between 210 and 269 metres, though a few live animals were obtained at a depth of 610 metres; off the coast of Persian Makran no life

\section{Arabian Coast}

\begin{tabular}{|c|c|c|c|}
\hline $\begin{array}{l}\text { Station } \\
\text { No. }\end{array}$ & $\begin{array}{l}\text { Depth } \\
\text { in } \\
\text { metres. }\end{array}$ & Character of bottom & Results. \\
\hline $\begin{array}{l}53 \\
80 \\
45\end{array}$ & $\begin{array}{c}13 \\
16-22 \\
40\end{array}$ & $\begin{array}{l}\text { Rock : Lithothamnionear. } \\
\text { Sand and Shells. } \\
\text { Lithothamnionea, etc. }\end{array}$ & $\begin{array}{l}\text { A good and varied catch. } \\
\text { A good oatch. } \\
\text { A good and very in- }\end{array}$ \\
\hline 43 & 83 & ? No sample obtained. & $\begin{array}{l}\text { A small but interesting } \\
\text { catch. }\end{array}$ \\
\hline $\begin{array}{l}79 \\
48\end{array}$ & $\begin{array}{l}102 \\
201\end{array}$ & $\begin{array}{l}\text { Green Mud }\left(\mathrm{H}_{\mathbf{3}} \mathrm{S}\right) \text {. } \\
\text { Rock. }\end{array}$ & $\begin{array}{l}\text { Very little animal life. } \\
\text { A very small catch. Net }\end{array}$ \\
\hline 77 & 350 & Green $\mathrm{Mud}\left(\mathrm{H}_{2} \mathrm{~S}\right)$. & A single crab; Paralia \\
\hline 56 & 457 & Green Mud $\left(\mathrm{H}_{2} \mathrm{~S}\right)$. & $\begin{array}{l}\text { No living organisms ; } \\
\text { dead shells of Ros- } \\
\text { tellaria delicatula and } \\
\text { Encephaloides arm- } \\
\text { strongi. }\end{array}$ \\
\hline 57 & $428-750$ & Green Mud $\left(\mathrm{H}_{2} \mathrm{~S}\right)$. & $\begin{array}{l}\text { Very little life; one dead } \\
\text { shell of Rostellaria } \\
\text { delicatula and a few } \\
\text { moribund Encephal }- \\
\text { oides armstrongi. }\end{array}$ \\
\hline 55 & 802 & Stratifled green mud. & No sign of living or- \\
\hline 54 & 952 & $\begin{array}{l}\text { Green mud and soft } \\
\text { rock. }\end{array}$ & $\begin{array}{l}\text { A good catch; thousands } \\
\text { of Ophiuroids. }\end{array}$ \\
\hline 58 & 1253 & Green mud $\left(\mathrm{H}_{2} \mathrm{~S}\right)$. & $\begin{array}{l}\text { A single crab : Para- } \\
\text { lomis sp. }\end{array}$ \\
\hline $\begin{array}{l}50 \\
59\end{array}$ & $\begin{array}{c}1536-1737 \\
1977\end{array}$ & $\begin{array}{l}\text { Brown mud. } \\
\text { Soft Green mud. }\end{array}$ & $\begin{array}{l}\text { Catch very small. } \\
\text { Catch very small. }\end{array}$ \\
\hline
\end{tabular}

was detected at a depth of 448 metres and it is somewhat significant that these levels correspond very fairly closely with the upper level of the deep inflowing mass of water that is running up the Gulf under the out-flowing Persian Gulf water. That this water is not per se responsible for the absence of life is clearly shown by the results of several horizontal hauls at depths down to as much as 1,500-2,000 metres, for at all depths numerous red deep-sea prawns and small fish, such as
Bregmaceros sp. and Scopelids, were obtained. It would appear, therefore, that the sterility of the area must be attributed either to some harmful character of the bottom deposit or else to some seasonal change in the general conditions of the deep water.

The surface waters and the inshore areas in both regions, in marked contradistinction, appear to be particularly fertile. Along the Arabian

\section{Gulf of Oman}

\begin{tabular}{|c|c|c|c|}
\hline $\begin{array}{l}\text { Station } \\
\text { No. }\end{array}$ & $\begin{array}{l}\text { Depth } \\
\text { in } \\
\text { metres. }\end{array}$ & Character of bottom. & Results. \\
\hline $\begin{array}{l}72 \\
71\end{array}$ & $\begin{array}{r}75 \\
106\end{array}$ & $\begin{array}{l}\text { Grey clay and shells. } \\
\text { Grey-green mud and } \\
\text { sand. }\end{array}$ & $\begin{array}{l}\text { A good and varied catch. } \\
\text { A moderate catch. }\end{array}$ \\
\hline 70 & 109 & $\begin{array}{l}\text { Soft green mud. } \\
\text { Soft green mud. }\end{array}$ & $\begin{array}{l}\text { Moderately good catch ; } \\
213 \text { living examples of } \\
\text { Rostellaria delicatula } \\
\text { and several Pirula sp. } \\
\text { A good catch. }\end{array}$ \\
\hline 67 & 269 & Soft green mud. & $\begin{array}{l}\text { No living organisms; } \\
\text { dead shells of Ros- } \\
\text { tellaria delicatula and } \\
\text { a few Serpulid tubes. } \\
\text { No signs of living or- }\end{array}$ \\
\hline 66 & 610 & Brownish-green mud. & $\begin{array}{l}\text { Several dead shells of } \\
\text { Rostellaria delicatula } \\
\text { and } 3 \text { living examples; } \\
\text { a few Serpulids. }\end{array}$ \\
\hline $\begin{array}{l}65 \\
68\end{array}$ & $\mid \begin{array}{c}912 \\
1491-1518\end{array}$ & $\begin{array}{l}\text { Green mud. } \\
\text { Soft green mud. }\end{array}$ & $\begin{array}{l}\text { No living organisms. } \\
\text { No living organisms. }\end{array}$ \\
\hline 81 & 3350 & Grey mud. & Two starftsh. \\
\hline
\end{tabular}

coast we have carried out several successful trawls, special attention being paid to areas where the charts indicate the presence of coral ; in every case we have found that true reef-forming corals are absent, though we have dredged a number of specimens of Lophohelia, Caryophyllia and F'labellum, some still living though many of them dead. The chief ingredient of the reef appears to be Lithothamnionex.

"Schott, G., "Uber die Wasserbewegungen im Bab el Mandeb". Ann. der Hydrographie und maritime Meteorologie, January 1929

${ }^{2}$ Matthews, D. J., "The Percy Sladen Trust Expedition to the Indian Ocean in 1905: No. VII. Physical Oceanography". Trans. Linn. Soc. London, 19, Part 1, 1926.

${ }^{3}$ Lloyd, R. E., "Contributions to the Fauna of the Arabian Sea with descriptions of new Fishes and Crustacea". Rec. Ind. BI 8 ., 1, Part 1, Calcutta, 1907.

\title{
Recent Discoveries at Choukoutien*
}

\section{By Prof. Davidson Black, F.R.s., Honorary Director, Cenozoic Research Laboratory, Geological Survey of China}

\section{Upper Paleolithic Culture in "Upper Cave" SEDIMENTS}

A

DETAILED account of the results of the Choukoutien excavations up to May 1933 has already been presented in our memoir "Fossil Man in China" (Mem. Geol. Surv. China. Series A, No. 11). In that report it was noted that above the Sinanthropus deposits there occurred towards the top of the hill a pocket of grey sediments of apparently modern facies, the site being described

\footnotetext{
- Report of excavations during the fleld season 1933, presented at
} the annual meeting of the Geological Society of China on November 11. as the "Upper Cave". During the past season, Mr. W. C. Pei has systematically investigated the deposits of the latter site, ably assisted by Mr. M. N. Pien. Their efforts have been rewarded by the discovery of much additional material of unexpected archæological significance.

(1) Sedimentary and lithological characters of Upper Cave deposits. The "Upper Cave" was a true cave but became completely filled with a mixture of grey cave loam and angular flat limestone fragments, the latter being derived from the collapsed portion of its roof. The roof is preserved over a quite large recess of the cave 
which extends to a smaller lower chamber not yet completely excavated. Where exposed, the cave walls are covered with stalactites and stalagmites. The grey Upper Cave sediments are largely unconsolidated and are in contact only over a few square metres with the hard red beds and stalagmitic floors capping the Sinanthropus strata of Locality 1. Elsewhere the Upper Cave appears to be developed as an independent system.

(2) Fauna of the Upper Cave. Though not very abundant, the Upper Cave fauna is remarkably rich in types and includes a puzzlingly large number of almost complete skeletons, the bones of which lie in correct association and are but slightly fossilised. The most interesting forms are as follows:- Hycena (an extinct species very different from that found in the Sinanthropus beds but similar to that of Sjara-osso-Gol) ; Felis tigris (entire skeleton); Cynailurus, which is now restricted to India (an entire skeleton); Viverra (no longer found in North China); the wild ass ; Equus hemionus; and the deer, Cervus elaphus (an entire skeleton), having antlers curiously similar to the special form from Sjara-osso-Gol.

(3) Human and cultural remains. In association with this fauna there occur both human skeletal remains and traces of industry. The skeletal remains are of modern type (Homo sapiens) and so far comprise two almost complete but somewhat crushed skulls, other skull fragments and teeth, fragmentary lower jaws, bones of the upper extremity (including one clavicle displaying a healed fracture), vertebræ, leg and foot bones. Traces of fire (charcoal and ash) are abundant.

There are three stone implements in a beautiful black chert, a well-made scratcher in vein quartz and several flakes and nuclei in vein quartz, and also a needle (eye broken), a deer canon bone worked at both ends, some thirty or more fox canine teeth perforated for necklace, an ornamental cylindrical piece made from a long bone of a bird, and a considerable quantity of oolitic hæmatite probably imported from a considerable distance. So far, no trace of pottery, polished stone or microlithic industry has been encountered.

Conclusions. The material recovered will shortly be made the subject of a full report and the conclusions here offered are wholly tentative, (a) The Upper Cave deposits appear to be decidedly younger than the Sinanthropus layers of Locality 1 , from which they are separated by stratigraphic and lithological disconformity and by a faunistic interval (absence of thick-jawed deer, occurrence of a special Hyana, presence of $C$. elaphus, $E$. hemionus, etc.). (b) The Upper Cave deposit is, however, probably also Pleistocene in age (collapsed cave, loess-like sediments, presence of Hyæna; cf. spelaea, Cynailurus, Viverra, E. hemionus, special deer, etc.). (c) In these circumstances, we are inclined provisionally to attribute the associated human remains to a Late Pleistocene, Palæolithic culture. The latter would seem to correspond approximately to the same stage as the Upper Palæolithic of Siberia and Europe. It appears, however, to be somewhat more advanced than the Ordos industries (Shui-tung-ko and Sjara-osso-Gol) in which no typically worked bones have thus far been found in certain association.

\section{Cynocephalus Remarns}

In a cylindrical solution cavity about a metre in diameter in the limestone to the south of Locality 1, Mr. M. N. Pien discovered this season a considerable number of fossil bones imbedded in a peculiar red deposit containing a large proportion of small well-rounded pebbles. These bones are remarkably fossilised and heavy, many of them being water-worn and rounded. A few, however, are well preserved, among the latter being several teeth and limb bones of a large baboon, probably Cynocephalus wimani, Schlosser. Strikingly similar deposits containing the same type of heavy rolled bone fossils have already been encountered at the very base of the Sinanthropus deposits of Locality 1 (Lower Cave). At the present stage of excavation it remains an open question whether or not these beds represent a pre-Choukoutien stage or merely correspond to an early phase in the last filling of the clefts.

In any case it would seem that one must conclude from this latest discovery that the Choukoutien fissures have been successively inhabited by baboons, by Sinanthropus and by a modern type of Homo. However, such a coincidence appears less extraordinary when it is recalled that though Ordovician limestone is widely distributed along the Western Hills, at Choukoutien, on account of its low anticlinal structure at the borders of the plain, it is exceptionally well situated for dissection into fissures and caves.

\section{Obituary}

Prof. J. Joly, F.R.s.

JOHN JOLY came of a remarkable lineage. His father's grandfather was a member of a French noble family. His mother, a German countess, whose family had been ennobled by Frederick the Great, was descended from Greek, Italian, and English ancestors. This mixture of blood, perhaps, may explain his ready sympathy with the most diverse personalities, his princely generosity which often gave to others what he denied to himself, and his versatility which enabled him to prosecute research in so many fields of knowledge, and to obtain æsthetic pleasure in the realms of art, literature, music and science.

Joly's earliest papers were mostly occupied with mineralogy. The beauty of the colour and form of minerals had a marvellous attraction for him. In this period he wrote on the ash of Krakatoa, beryl, iolite and harmotome. Investigation on these minerals led him to devise the meldometer and 